Reflected places of childhood: Applying the ideas of humanistic and cultural geographies to environmental education research

\title{
Tani, Sirpa
}

2017

Tani , S 2017 , ' Reflected places of childhood: Applying the ideas of humanistic and cultural geographies to environmental education research ' , Environmental Education Research , vol. 23 , no. 10 , pp. 1501-1509 . https://doi.org/10.1080/13504622.2016.1269875

http://hdl.handle.net/10138/307781

https://doi.org/10.1080/13504622.2016.1269875

acceptedVersion

Downloaded from Helda, University of Helsinki institutional repository.

This is an electronic reprint of the original article.

This reprint may differ from the original in pagination and typographic detail.

Please cite the original version. 
Pre-print version

See the published version: Environmental Education Research 23: 10, 1501-1509.

http://dx.doi.org/10.1080/13504622.2016.1269875 (2017)

\title{
Reflected places of childhood: applying the ideas of humanistic and cultural geographies to environmental education research
}

Sirpa Tani

Faculty of Educational Sciences, University of Helsinki, Helsinki, Finland

\begin{abstract}
The article investigates people-environment relationships from the viewpoint of humanistic and cultural geographies and highlights the importance of subjective experiences and emotional place attachment in the construction of environmental attitudes. Some core concepts of these research fields (e.g. 'place', 'insideness/outsideness', 'topophilia/topophobia) are defined and their meanings for environmental relations are interpreted. Empirical material is based on the written essays of 65 students who participated in the Introduction Course of Environmental Education at the University of Helsinki, Finland. The analysis concentrated on students' childhood memories to find out what kind of environmental experiences were regarded as significant from the adults' perspective. The essays showed how the students' environmental attitudes were not always based on their experiences of nature but their connection to the environment could also be constructed in urban settings. The role of everyday environments and other people during childhood years were regarded as essential elements in constructing close bonds with the environment.
\end{abstract}

Keywords: place; environment; sense of place; humanistic geography; cultural geography

\section{Introduction}

This research investigates people's personal relationships with their environment. Outdoor- and nature-related experiences and participation in activities of environmental organisations have often been regarded as the most important factors in constructing positive attitudes towards environment (e.g. Tanner 1980; Chawla 1998a; Palmer et al. 1999; Sward 1999; Hsu 2009; Li and Chen 2015). The majority of the studies of significant life experiences have concentrated on quantitative analyses of elements identified as important for the activists' environmental attitudes (on qualitative approaches, see Chawla 1998b). Some criticism, however, has been presented against these studies, for example, of placing only the environmental activists into the focus; concentrating mainly on positive experiences and their effects; researching mainly adults' views of their childhood experiences; and not mentioning how the research findings could be applied in pedagogical practices (see e.g. A. Gough 1999; S. Gough 1999; Payne 1999). Ceaser (2015, 216) has argued that more sociological understanding of emotions and experiences would be needed to be able to connect 
people's personal experiences to their decision to become environmental activists. It is also worth mentioning that there is an important approach often missed in the studies of significant life experiences and its critique: the meaning of urban environments in constructing bonds between people and their environments (however, see Russ et al. 2015).

This article resonates with Ceaser's (2015) plea for approaches that would pay special attention to the role of emotions and people's personal experiences. These will be investigated by introducing conceptualisations of humanistic and cultural geographies, which have seldom been applied into the context of environmental education research. They are argued to have the potential to widen the horizon of the environmental education research towards more reflective perspectives. The aim is thus not to find causal relations between environmental experiences and environmental behaviour or attitudes, but to take a closer look at the ways in which people tell about environments that matter for them. Their stories can offer us some deeper understanding of the process in which the unique relation to the environment is constructed.

The intention of the article is to develop understanding of subjective environmental experiences, which will be undertaken by introducing some central concepts of humanistic geography. Special attention will be paid to 'sense of place', 'place attachment', 'topophilia' and 'places of fear' ('topophobia'). These concepts will be then used to interpret empirical material that was gathered during the introductory course on environmental education at the University of Helsinki, Finland. While the emphasis will be on the conceptual level, the analysed material will be used as illustrations in this theory-driven process. Therefore, conceptual and empirical elements are intertwined in the text.

Next, methodological choices and the gathered data will be described before the main viewpoints and concepts derived from humanistic geography are introduced. Then the perspective will be moved from subjective experiences towards shared elements in people-environment relations. The article will be concluded by highlighting the value of self-reflection of subjective experiences for environmental educators and by emphasising the importance of emotions in environmental education research.

\section{Methodology and material: reflected childhoods}

'Children's geographies' has been a growing research field during the recent decade. The launch of the journal with the same name in 2003 (see Matthews 2003) and publication of edited volumes on research with children and young people (e.g. Fraser et al. 2004; Christensen and James 2008; Thomson 2008; Tisdall, Davis and Gallagher 2009; Groundwater-Smith, Dockett and Bottrell 2015) are just some of the many examples of the multidisciplinary interest in the field. As the titles of the edited books mentioned above reveal, there have been many contributions for developing research methodology in order to gain access to children's and young people's experiences and emotions. The common aim for the most of these studies has been the attempt to think children and young people as active and competent subjects in the research process, not as objects of research. Researching with children and young people has thus become a common procedure in childhood and youth studies.

In this article childhood memories and meaningful places are seen and reflected from distance; from the viewpoint of university students who have re-presented their memories of places that have had some effect on the ways in which they think about different environments in present day. The idea of researching childhood experiences from adults' perspective is not a new one. In 
children's geographies childhood as memorized has been investigated for example by Jones (1997, 2003) and Philo (2003). Jones $(1997,176)$ has pointed out that '[w]e have all been "children", or at least biologically young - so we have all been that other once and may still contain some form or traces of it.' Elsewhere, however, Jones has stressed the difference between children's experiences and the interpretations made from adults' perspective and noted how adults could never reach their childhood experiences like they were when they were children. He wrote: 'Once childhood is superseded by adult stocks of knowledge, those filters can never be removed to get back to earlier states. Adult constructions and memories of what it is/was to be a child are invariably processed through adultness.' (Jones 2001, 177) Horton and Kraftl (2006), admitting this, have highlighted the value of adults' perspectives on children's geographies in their research that was based on their reflections of everyday memories of their personal histories. They argued that 'adults' memories of childhood are significant in and of themselves, not least in allowing us to consider how the issues that mattered in childhood were and are remembered or witnessed today, and how they live on in adults' lives' (Horton and Kraftl 2006, 269). For them, materiality was also seen important in the process of constituting memories, while 'memories and emotions are frequently attached to specific objects', as they wrote later in the article that dealt with their detailed narrations of cataloguing the contents of three cupboards. With the help of these vignettes, they showed how material objects and memories were intertwined and thus carried meanings that could be identified with the help of these material things (Horton and Kraftl 2012, 28). In this article, I agree with Horton and Kraftl on the importance of childhood memories for adults' ideas of their personal bond with their environment. Even when childhood experiences can never be reached per se, they still affect adults' appreciation of certain types of environments. Following text will be thus based on the subjective meanings that the adult students were describing in their essays.

The research material was collected in the end of the Introduction Course of Environmental Education at the University of Helsinki, Finland. The course available for all the students of the university is organised once a year and consists of lectures and students' individual written work. The course can be selected as part of the minor subject studies called 'Environmental multidisciplinary study module' organised by the Helsinki University Center for Environment, but it can also be taken as a separate course. Even when the students' backgrounds were diverse, they shared an interest to environmental issues when they attended this voluntary course. The objective of the course was to make an overview on the field of environmental education: its background and main elements were investigated in the lectures and the course literature. In addition to the evaluated material, the students were asked to reflect their personal place attachment in short essays (3-5 pages). They were asked to describe the factors that had been shaping their ideas of the environments that they regarded as interesting or important. They could also write about the environments where they felt being at home - about their personal 'sense of place'. The 'environment' was investigated in the broad sense of the word; both natural and human elements were investigated in the course. Students were asked to reflect their own relationship with different environments to make them conscious of the factors that have affected their present ideas of interesting environments.

The material interpreted in this article was gathered from the participants attending the course in 2013 and 2015. In total, 67 students completed the course and 65 of them gave their consent to use their work for research purposes. Sixty of them were female, and only five male students. The majority of the students (51 of them) were in their twenties, 13 in their thirties, and one student in her fifties. They were told that the material they produced would not have any effect on grading of the 
course and that their identities could not be traced from the research articles. The participants came from seven faculties: they represented biological and environmental sciences (29\%), science (26\%), agriculture and forestry (17\%), behavioural sciences (12\%) and arts (9\%). One student came from social sciences and one from veterinary sciences. There were two students whose faculty could not be traced from the material available. For the purposes of this research, the multidisciplinary mixture of students' backgrounds was seen as an interesting point of departure. The aim of this article is not, however, to make any analysis of the possible correlation of students' major subjects and their ideas of meaningful environments - the number of the students is not adequate for that. This information of their background worked as a background knowledge during the process of reading and analysing the material.

The selected approach for this article is based on theory-driven analysis of this material: students' writings are used as illustrations of the introduced perspectives while the focus is on investigation of the potential of geographical research for environmental education research. The analysis was started by carefully reading all the essays to get an overview of the material. While the research was decided to be conducted as theory-driven, the second round of reading was concentrated on identifying the environments that were carrying some special meanings for the students. These descriptions were then gathered together under some working titles (e.g. 'meanings of home'; 'attachment to nature'; 'attachment to urban environments'; 'meanings of other people') and these quotations were then read again in order to find cross-cutting themes that would resonate with the ideas of humanistic and cultural geographies in the context of research on environmental education. The analysis was conducted by one researcher only, which could be seen as affecting the level of reliability and validity in the study.

The interpreted material in this article is used to illustrate diverse elements of peopleenvironment relations that the respondents themselves regarded as important for their own environmental attitudes. The analysis is hoped to offer ideas that could be used in the studies of environmental education in other contexts. The main goal of this article is thus not to report an empirical study but to develop conceptual understanding of subjective bonds between people and their environment and to highlight their relevance for environmental education.

\section{Emotional bond between human being and the environment}

The background ideas of this article come from the tradition of humanistic geography. In the 1970s some geographers started to pay increasing attention to subjective ways in which people attached meanings to different environments. Yi-Fu Tuan, the most well-known of the humanistic geographers, based his thinking on existentialism and phenomenology when he wrote on the processes where a human being - by observing, experiencing, living, imagining and dreaming attached meanings to her/his environment and thus converted the abstract space into a unique place filled with meanings. Tuan wrote about this meaningful attachment as a 'sense of place' (Tuan 1977), and as 'topophilia', which he defined as 'an affective bond between people and place or setting' (Tuan 1974, 4). Meanings of 'place', 'sense of place' and 'place attachment' have not only been investigated in geography but also, for example, in sociology (e.g. Gustafson 2001; Stedman 2003) and environmental and social psychology (e.g. Chawla 1992; Hidalgo and Hernándes 2001; Manzo 2005; Kudryavtsev, Stedman and Krasny 2012). There is no space to review this literature in spite of its 
many interesting aspects here; instead, the aim is to apply the ideas of geography to environmental education research.

Relph (1976), another classic from the phenomenology-based studies on place, paid attention to the alienating character of modern architecture. He wrote about places but also about 'placelessness', by which he meant the physical settings that were detached from their context by their looks or character. For example, modern airports, shopping malls and offices of multinational corporations could be seen as placeless places (see also 'non-places' by Augé 1995). Relph was also interested in people's personal bonds with their environments. 'Existential insideness' defined by him meant the feeling of being part of the environment, strongly connected to the place, whereas its opposite, 'existential outsideness', referred to total detachment or alienation from the environment (Relph 1976). For both Tuan and Relph, 'sense of place', as well as 'identity with the place', was constructed by living and attaching meanings to surrounding environments; insideness thus meant more than just being born or raised somewhere, and sense of place was actively shaped by person's intentionality. This means that 'place' was seen not as a stagnant entity, but as a dynamic context where meanings were produced and re-produced over time; the person-environment relationship was thus seen as an on-going process (see also Lim and Barton 2010, 330).

Students who participated this research by writing their essays gave detailed descriptions of important places in their childhood. Many of their stories were connected to the time spent in forest. A female student described a variety of meanings that she attached to the forest located nearby her childhood home:

This forest was important for me because it was an excellent place for playing. When I grew up it became a place for chilling out; I walked our three dogs there and sometimes went there by myself. When the new buildings were constructed nearby, I thought that I still have that forest where I could be by myself and close to nature. So, when I heard that the forest would be cut down, I felt sad. Fortunately a small part of it was left uncut. I go there to have a walk when I'm visiting my parents and then I think back to the old plays and walks.

The quotation above shows how the respondent attached different meanings during the years to the same environment. As a child, the place had meant a site of playing and exploring while in her teenage years she had regarded it as an important place for reflection and relaxation. From the adult's perspective, she described the sadness of losing some of the essence of her place because of the changes it has witnessed but she also mentioned how some of its meanings were still remaining.

This excerpt represents one of the many stories where the participants described the changes that their childhood environments had been going through. From the perspective of humanistic geography, the uniqueness of place and personal attachment to it (see Tuan 1977) can be clearly seen in this description: the meaning that the environment has cannot be detached from its experiencer; it is not something that could be analysed by its physical characteristics, but it is constructed by an individual through living and experiencing it. Using the vocabulary of the humanistic geography: when the students described environments that carried personal meanings for them, they wrote about the process in which 'environment'turned into a unique place for them. 
For some students, a certain type of environment carried positive childhood memories and therefore the same kind of environments were also regarded as important in their adult life. A female student, who had moved to Finland after her childhood years, attached strong feelings to seashores regardless of their location: her positive feelings were not attached to the specific location but the essence of the sea and seashore was important for her. Reason for this was her early childhood memories, which she described in detail:

I spent my childhood years close to the sea, and woke up with the sound of waves and warm wind coming from the sea in the morning. Our home in the city centre as well as our summer cottage was by the seaside. I have so many great memories attached to the seaside that I find it difficult to think myself living inland ever. Just seeing the sea gives me a feeling that cannot be replaced by any other environment.

Even when the source of meaningful environmental experiences can be traced to some specific locations and memories as the example above indicates, it is possible to apply the positive attitude to new environments later in life when some similar elements can be identified (see also Horton and Kraftl 2006). Humanistic geographers' main interest was in the construction of place attachment, 'topophilia', while its opposite, 'topophobia', did not awaken equal amount of interest at that time (Porteous 1987, 34). Koskela (2010) has later analysed the ways in which the emotion of fear has been investigated in geographical research. According to her, humanistic geographers saw fear as 'an individual emotion, part of the sense of place'; phobias, experiences and memories were seen as contributing in the production of fear (Koskela 2010, 392).

While the most of the stories written in the essays described positive memories of childhood, there were, however, some that revealed unpleasant memories attached to certain environments. For some of the students who had later got interested in natural environments, childhood memories were telling a different story, that of unpleasant experiences:

As a child I found forests and lakes often unpleasant because there were usually gadflies, mosquitos, snakes and darkness in there. I remember many occasions when I definitely wanted to stay home in the centre to play and not by any means to go hiking to a national park or to pick berries in the nearby forest.

Some students wrote about places of fear (Tuan 1974; Koskela 2010) in their essays. Fear was sometimes attached to animals or darkness as the quotation above shows, but quite often it was connected with social elements in the environment: other people made children feel uncertain or fearful. These feelings had transferred to their adult life so that the same environment could still awaken the feelings of being afraid. A female student described her topophobic experiences:

I had to pass by this place daily on my way to daycare, during my first two years in primary school and to visit my friends' places. ... The place and the environment caused a strong sense of fear for many years, and in fact, even today.

Relph (1976) defined 'existential outsideness' as a person's feeling of detachment of his/her daily surroundings - experience of not belonging there. Some of the students wrote about their feelings of 
loneliness and 'outsideness' in their essays, like the following excerpt from a female student shows. For her, the importance of place was only revealed when she had to leave it behind:

I didn't really have any friends when I was at the first grade in school and therefore I was often alone. ... In the house I had my own room but I didn't want to be there because I felt lonely there. I thought that I would regard that house as a strange place for me until the day came when I had to move away from there. My parents separated and the house was sold. I wouldn't want to give up that place at all.

There were some other topophobic or otherwise negative place experiences described in the students' essays, but the excerpt above was exceptional in its powerful tone of existential outsideness. It was selected here as an example to show how even the negative environmental experiences could change their nature during the life course when a person's position - or sometimes the environment itself was changing.

\section{Shared character of environmental experiences}

Humanistic geography of the 1970s encountered criticism from different perspectives. First, it was argued that the approach ignored wider aspects of society (e.g. questions of inequality) that were relevant in constructing people's relationships with their environments. Second, there was criticism against its way to highlight the positive attachment to 'home'; feminist geographers highlighted the point that home was not always a positive place - for example, for many women it could be a place of fear because of domestic violence and abuse (see e.g. Rose 1993, 55; Blunt and Dowling 2006, 14). Third, critique was also presented against too simplistic attitude towards place attachment: it was argued that all the people living in the same location did not have same kinds of opportunities to enjoy the positive elements of the environment (about this discussion, see Duncan and Duncan 2001, 41). Fourth, it was argued that humanistic geographers, when concentrating on the uniqueness of environmental experiences, did not pay enough attention to the shared dimension of experiences (see e.g. Koskela 2010, 392).

Despite all the criticism, the main strengths of the humanistic approach to peopleenvironment relationships have been acknowledged, especially in contemporary cultural geographies. After the cultural turn in geography of the 1990s, some geographers started to pay attention to the everyday geographies, where personal bonds with mundane surroundings were seen as important (e.g. Philo 2000). There were traces from humanistic geography but its ways to investigate the lifeworld were re-interpreted, not as much as the unique bonds but more as constructed in the processes where subjective and intersubjective meanings came together. The role of cultural products and mediatized images of the world were seen essential in constructing relationships with the environment. For example, Chris Philo (2000) stressed the importance of research of banal environments, everyday spatial experiences and their embodied characters. Doreen Massey ([1991] 1994) combined the ideas of personal place experiences with the tradition of critical social geography in her writings on 'global sense of place'; she analysed the meaning of place in a time of globalization, and from the viewpoint of 'time-space compression'. She saw 'place' not as static but always in flux, conceptualized in social interactions, and having multiple identities. 
In the students' childhood memories the environment was regarded meaningful most often when there had been opportunities to actively explore it. Necessarily it did not seem to matter whether it was natural, rural or urban environment; what mattered though was their opportunity to construct their relation to the environment. This relation was not constructed in a vacuum but in interaction with other people: parents and other relatives were important co-agents in the construction process of emotional bonds, as were other children with whom the environment was explored. Personal 'place' could be shared with the friends; it then turned into a 'social space' that was important also to the others:

In the place where I was living, there were many spaces to play for children: the rocks, the trees, sandpits and climbing frames at our own courtyard, but also playgrounds, parks, forests and beaches that were close to home. Inside places for play were your own home or your friends' homes.

For those students who had spent their childhood in urban areas, forests and wastelands as well as summer cottages in the countryside had offered links to natural or unbuilt areas. Wastelands and small groves were not necessarily regarded as aesthetically pleasant but when they offered good places for exploring and playing, they were highly valued for children's point of view:

Our nearby forest was not maybe the totally safe place to play in because every now and then from the moats we found some hollows and small places to live constructed by some junkies and alkies. We were never afraid anyway, and our parents were not concerned about us. We knew how to be cautious and careful.

The excerpt above demonstrates one of the essential characteristics of subjective meanings that one can attach to the environment: 'sense of place' is not necessarily something that could be recognised by the outsiders; it is constructed by an individual as a result of connecting positive meanings to a specific environment. For children, 'forest' did not have to be any large area to feel like a forest. For many of them, small parks, a couple of bushes or trees could mean places for expeditions and imaginations. Everyday environments with their banal characteristics could carry important meanings for children:

In my childhood I was often playing in a small thicket that was close from my friend's home. It felt like a real forest then when I was a child.

Raittila (2012) has described this in the context of day care, where she gathered material with children for her research. She made 'expeditions' with small groups of children in the same quarter where the kindergarten was located. During the trips, some children played 'jungle' in a spot that from adult's point of view had only some bushes. When these kinds of meaningful places from childhood are later visited, many adults easily feel confused when the imagined forests turn out to be just modest bushes. This kind of observation can reveal some of the hidden meanings in adults' ways to value certain types of environments: there may be some childhood experiences affecting their emotions and thus shaping their environmental attitudes. 
Even when emotional attachment to environment is unique and constructed through personal experiences like humanistic geographers understood it (e.g. Tuan 1974, 1977), these relations with the environment are never constructed in a vacuum but always in connection with other people. Many of the students described this aspect in their essays. They wrote detailed descriptions of their environmental experiences in their childhood. For many of them, outdoors close to their home, summer cottage or their grandparents' homes were important places to which they still attached deep meanings. In those stories, physical and social environments were often intertwined (about the social component of memories, see Liddicoat and Krasny 2014).

A place itself does not generally mean anything to me unless there are some dear people

or exciting acquaintances involved. Environments that are important for me are often comprised of people. When the adults around the child had a close relationship with the environment, they often managed to enhance the same kind of appreciation of the environment in their children's lives. Adults in these cases were seen as important role models; their role as environmental educators in everyday life of the respondents was mentioned in some essays.

\section{Conclusion and discussion}

The aims of this article were twofold. First, it was written to take a closer look at significant life experiences of people who have shown some interest in environmental education. Reading the students' essays showed clearly how the background of their environmental attitudes was not necessarily based on their childhood experiences of nature (for many, nature had been and still was important though) but the close connection to the environment could also have been constructed in urban settings. What was common to all of them was the personal connection to their everyday environment. The role of other people was essential in building that bond.

Second, the article was written to introduce the main ideas of traditional humanistic geography and contemporary cultural geographies, especially the methodological and conceptual 'tools' that they offer to studies of people-environment relationships. It is argued that geographical understanding of 'place', 'sense of place' and 'place attachment' has important potential that could be applied in academic courses of environmental education and in the research of environmental educators' significant life experiences. When 'environment' is defined as consisting of natural and built as well of social elements, our understanding of the process of constructing people-environment relationships can be widened. More research on emotional aspects of place attachment would be welcome, for example by including everyday environments into the focus of research and by closely analysing people's subjective environmental experiences.

The research reported in this article is hoped to offer some ideas for other researchers of environmental education. The analysed essays showed how this kind of self-reflection could be fruitful for future environmental educators (as the students attending the course could be defined): writing the essays made them think about their childhood experiences in a fresh way. For many of them, seemingly small details had been important in the process where their personal relationship with the environment had been constructed. It is also worth mentioning how these students who were interested in environmental issues and environmental education came from diverse backgrounds; some of them had close relationship with nature since their childhood years, while some others had their roots in urban environments; some of the students even described unpleasant memories of natural environments in their essays. What was common to all of them was their genuine interest in 
the environment. This can be seen as the main message of this research: people can become interested in environmental issues regardless of their childhood environments. When they have opportunities to explore their daily environments by themselves and with other people, the environment becomes meaningful - a sense of place is created. Personal reflections are thus needed in the process of enhancing environmental sensitivity and appreciation of different environments.

\section{References}

Augé, M. 1995. Non-places: Introduction to an Anthropology of Supermodernity. Translated by J. Howe. London: Verso.

Blunt, A., and R. Dowling. 2006. Home. London: Routledge.

Ceaser, D. 2015. "Significant Life Experiences and Environmental Justice: Positionality and the Significance of Negative Social/Environmental Experiences." Environmental Education Research 21 (2): 205-220.

Chawla, L. 1992. "Childhood Place Attachment." Human Behavior and Environment 12: 63-86.

Chawla, L. 1998a. "Significant Life Experiences Revisited: A Review of Research on Sources of Environmental Sensitivity." The Journal of Environmental Education 29 (3): 11-21.

Chawla, L. 1998b. "Research Methods to Investigate Significant Life Experiences: Review and Recommendations." Environmental Education Research 4 (4): 383-397.

Christensen, P., and A. James, eds. 2008. Research with Children: Perspectives and Practices. 2nd ed. London: Routledge.

Duncan, J. S., and N. G. Duncan. 2001. "Sense of Place as a Positional Good: Locating Bedford in Space and Time." In Textures of Place: Exploring Humanist Geographies, edited by P. C. Adams, S. Hoelscher, and K. E. Till, 41-54. Minneapolis: University of Minnesota Press.

Fraser, S., V. Lewis, S. Ding, M. Kellett, and C. Robinson, eds. 2004. Doing Research with Children and Young People. London: Sage \& The Open University.

Gough, A. 1999. "Kids Don't like Wearing the Same Jeans as Their Mums and Dads: So Whose 'Life' Should Be in Significant Life Experiences Research?” Environmental Education Research 5 (4): 383-394.

Gough, S. 1999. "Significant Life Experiences (SLE) Research: A View from Somewhere." Environmental Education Research 5 (4): 353-363.

Groundwater-Smith, S., S. Dockett, and D. Bottrell. 2015. Participatory Research with Children and Young People. London: Sage.

Gustafson, P. 2001. "Meanings of Place: Everyday Experience and Theoretical Conceptualizations." Journal of Environmental Psychology 21: 5-16.

Hidalgo, M. C., and B. Hernándes. 2001. "Place Attachment: Conceptual and Empirical Questions". Journal of Environmental Psychology 21: 273-281.

Horton, J., and P. Kraftl. 2006. "Not Just Growing Up, but Going on: Materials, Spacings, Bodies, Situations." Children's Geographies 4 (3): 259-276.

Horton, J., and P. Kraft1. 2012. "Clearing out a Cupboard: Memory, Materiality and Transitions." In Geography and Memory: Explorations of Identity, Place and Becoming, edited by O. Jones and J. Garde-Hansen, 25-44. Basingstoke: Palgrave Macmillan.

Hsu, S.-J. 2009. "Significant Life Experiences Affect Environmental Action: A Confirmation Study in Eastern Taiwan.” Environmental Education Research 15 (4): 497-517. 
Jones, O. 1997. "Little Figures, Big Shadows: Country Childhood Stories." In Contested Countryside Cultures: Otherness, Marginalisation and Rurality, edited by P. Cloke and J. Little, 158179. London: Routledge.

Jones, O. 2001. “"Before the Dark of Reason': Some Ethical and Epistemological Considerations on the Otherness of Children." Ethics, Place \& Environment 4 (2): 173-178.

Jones, O. (2003). "Endlessly Revisited and Forever Gone: On Memory, Reverie and Emotional Imagination in Doing Children's Geographies. an 'Addendum' to 'To Go Back up the Side Hill: Memories, Imaginations and Reveries of Childhood' by Chris Philo." Children's Geographies 1 (1), 25-36.

Koskela, H. 2010. "Fear and Its Others." In The SAGE Handbook of Social Geographies, edited by S. J. Smith, R. Pain, S. A. Marston, and J. P. Jones III, 389-407. London: Sage.

Kudryavtsev, A., R. C. Stedman, and M. E. Krasny. 2012. "Sense of Place in Environmental Education." Environmental Education Research 18 (2): 229-250.

Li, D., and J. Chen. 2015. "Significant Life Experiences on the Formation of Environmental Action among Chinese College Students." Environmental Education Research 21 (4): 612-630.

Liddicoat, K. R., and M. E. Krasny. 2014. "Memories as Useful Outcomes of Residential Outdoor Environmental Education.” The Journal of Environmental Education 45 (3): 178-193.

Lim, M., and A. C. Barton. 2010. "Exploring Insideness in Urban Children's Sense of Place." Journal of Environmental Psychology 30: 328-337.

Manzo, L. C. 2005. "For Better or Worse: Exploring Multiple Dimensions of Place Meaning." Journal of Environmental Psychology 25: 67-86.

Massey, D. (1991) 1994. A Global Sense of Place. Marxism Today, June 24-29. Reprinted in D. Massey. 1994. Space, Place and Gender, 146-156. Cambridge: Polity Press.

Matthews, H. 2003. "Coming of Age for Children's Geographies.” Children's Geographies 1 (1): 35.

Palmer, J. A., J. Suggate, I. Robottom, and P. Hart. 1999. "Significant Life Experiences and Formative Influences on the Development of Adults' Environmental Awareness in the UK." Australia and Canada. Environmental Education Research 5 (2): 181-200.

Payne, P. 1999. "The Significance of Experience in SLE Research." Environmental Education Research 5 (4): 365-381.

Philo, C. 2000. "More Words, More Worlds: Reflections on the 'Cultural Turn'and Human Geography." In Cultural Turns/Geographical Turns: Perspectives on Cultural Geography, edited by I. Cook, D. Crouch, S. Naylor, and J. Ryan, 26-53. Harlow:Prentice Hall.

Philo, C. 2003. "To Go Back up the Side Hill: Memories, Imaginations and Reveries of Childhood." Children's Geographies 1 (1): 7-23.

Porteous, J. D. 1987. “Deathscape: Malcolm Lowry's Topophobic View Of The City.” The Canadian Geographer 31 (1): 34-43.

Raittila, R. 2012. "With Children in Their Lived Place: Children's Action as Research Data." International Journal of Early Years Education 20 (3): 270-279.

Relph, E. 1976. Place and Placelessness. London: Pion.

Rose, G. 1993. Feminism and Geography: The Limits of Geographical Knowledge. Minneapolis: University of Minnesota Press. 
Russ, A., S. J. Peters, M. E. Krasny, and R. C. Stedman. 2015. "Development of Ecological Place Meaning in New York City.” The Journal of Environmental Education 46 (2): 73-93.

Stedman, R. C. 2003. "Is It Just a Social Construction? The Contribution of the Physical Environment to Sense of Place." Society \& Natural Resources 16 (8): 671-685.

Sward, L. L. 1999. "Significant Life Experiences Affecting the Environmental Sensitivity of El Salvadoran Environmental Professionals." Environmental Education Research 5 (2): 201-206.

Tanner, T. 1980. "Significant Life Experiences: A New Research Area in Environmental Education." The Journal of Environmental Education 11 (4): 20-24.

Thomson, P., ed. 2008. Doing Visual Research with Children and Young People. London: Routledge. Tisdall, K., J. M. Davis, and M. Gallagher. 2009. Researching with Children and Young People: Research Design, Method and Analysis. London: Sage.

Tuan, Y.-F. 1974. Topophilia: A Study of Environmental Perception, Attitudes, and Values. Englewood Cliffs, NJ: Prentice-Hall.

Tuan, Y.-F. 1977. Space and Place: The Perspective of Experience. Minneapolis: University of Minnesota Press. 